\title{
How Far Disaster Management Implemented Toward Flood Preparedness: A Lesson Learn from Youth Participation Assessment in Indonesia
}

\author{
Edi Kurniawan ${ }^{1}$, Erni Suharini ${ }^{*}$, Muchamad Dafip ${ }^{2}$ \\ ${ }^{1}$ Geography Department, Faculty of Social Sciences, Universitas Negeri Semarang, Sekaran Campus, Gunungpati, Semarang \\ 50229, Indonesia \\ ${ }^{2}$ Yayasan Kognisi, Department of Research and Development, Patemon, Gunungpati, Semarang 50228, Indonesia
}

Corresponding Author Email: erni.suharini@mail.unnes.ac.id

https://doi.org/10.18280/ijsse.110206

Received: 17 August 2020

Accepted: 26 February 2021

\section{Keywords:}

youth, disaster mitigation, participation

\begin{abstract}
Flood is a common and frequent natural disaster in many countries that causes huge economic losses and casualties every year. Youth participation in flood disaster management (FDM) has not been much explored, especially in the non-prone area but contributing to flooding resilience. Therefore, this study aims to identify youth participation in disaster management to help an improvement in preparedness action. The research was conducted using a qualitative model: case study research, involving 191 young people aged 14-35-years in 16 sub-districts in Semarang City. The data, including youth's action, knowledge, and participation in FDM, was collected using Google Form, observation, and interview, then statistically analyzed using Mann-Whitney's test and path analysis. The results show the respondents in flood-affected areas are more actively participating in flood disaster management action because of their experience in facing flooding. Also, the planning step is significantly influenced by the FDM implementation. The planning process is the main defining factor in disaster management successfulness and essentially affecting mitigation, rehabilitation, and evaluation steps. The level of youth participation is deemed necessary to be increased to develop a more comprehensive disaster management program according to regional needs. We suggest that FDM should be transformed into disaster awareness which is delivered through education, socialization, training, and/or flood disaster response simulations.
\end{abstract}

\section{INTRODUCTION}

Natural disasters are incidents that cannot be predicted. Floods, droughts, forest fires, storms, pandemic diseases, and landslides occur due to climate variations in certain areas [13]. Countries such as China, Philippines, Pakistan, and Indonesia are the ones experiencing approximately 55\% damage due to natural disasters in Asia during 2015 [4]. Flood is a common and frequent natural disaster in many countries that causes huge economic losses and casualties every year, seriously restricting the sustainable development of society and economy.

Indonesia is a country whose territory has been flooded every year for the past decade $[5,6]$. Semarang City, one of the major cities in Indonesia, is affected by climate change and often experiences flashflood and inundation [7]. Over the past four years, at least as many as 62 times the flood hits Semarang City with a high repetition frequency of incidents each year [8]. It makes economic losses and forces the coastal community to migrate from their home to safer places (up-town) [9-11].

The high level of floods in Semarang City needs to be balanced with improved awareness and preparedness for disasters from all elements of society, especially youth [12, 13]. In Semarang City, empowerment activities are conducted involving the community to help them preparing disaster management, mitigation, adaptation, and recovery after the hit [14]. Several activities consist of activating flood early- warning system [15], establishing a disaster-preparedness group [16], involving academicians in flood disaster hazard potential mapping [17-19], and policy study [20].

In previous research, it is found out that the disaster preparedness action and critical thinking skill of youth in Semarang City in facing flood are still low [21], This is unfortunate, as the youth is expected to be more actively involved in community action in enhancing their resilience [22]. Active youth participation is expected to have a positive effect on solving problems related to flooding such as spreading positive information to gain community confidence after the disaster and accelerating rehabilitation [23]. The youth play an important role in improving disaster management because they excel in science, entrepreneurship, technology, and information [24]. Youth have high creativity, confidence, and courage in voicing new ideas so that the usefulness in reducing disaster risk will be very high $[12,13$, 25, 26].

Youth involvement in handling post-disaster recovery is important because it can escalate community resilience [27, 28]. Even so, generally, youth is still easy to experience difficulties in integrating the experience and knowledge they obtain from various sources such as schools, media, and government [12, 29, 30].

However, youth involvement in disaster management plans needs to be assessed based on the community's needs and capacities. Thus, an assessment of youth's capacity should be 
carried out to help stakeholders and the community decide how and where the youth will be settled in the disaster management plan. This study proposes to identify the youth participation level in disaster management in Semarang City as a basis for developing a comprehensive community-based disaster management plan.

\section{METHOD}

This research was a case study involving youth in 16 districts of Semarang City as respondents. The selection of flood-affected locations in this study was based on 1) have been or frequently affected by flood either due to overflowing river water or tidal flooding (Figure 1);2) have received a community-based program in disaster preparedness. The unaffected locations cover all areas in Semarang City that have not been affected by floods.

A total of 191 respondents aged 14-35 years were included in this study (Table 1). The selection of respondents at these ages refers to the context of technological development. Young respondents also have broad access to information and have good information management. So, the possibility of accessing technology is greater [31]. Respondents were obtained by the snowballing sampling method. Data collected includes data on youth participation in the implementation of disaster management to deal with floods.

The data were obtained from filling in 29 closed statements in the Google Form-based questionnaire instrument, developed from Regulation of the Republic of Indonesia Number 24 of 2007 on Disaster Management. This regulation is the main law used by Indonesian National Board for Disaster Management (BNPB) to determine disaster management activities. The statements that have been developed were grouped based on the stages of disaster management consisting of 1) pre-disaster of floods including planning and mitigation; 2) during a disaster including emergency response and adaptation, and 3) post-disaster consisting of rehabilitation/recovery and evaluation. The instrument was also compared to the previous research conducted by Cox and Hamlen [32] to increase the targeted respondent's understanding and perspective of the statements.

Table 1. Respondents' demographic data

\begin{tabular}{ccccc}
\hline \multirow{2}{*}{ Variables } & \multicolumn{2}{c}{ Unaffected } & \multicolumn{2}{c}{ Affected } \\
\cline { 2 - 5 } & $\sum$ Resp. & $\%$ & $\sum$ Resp. & $\%$ \\
\hline Ages (years old) & 93 & & 98 & \\
$18-23$ & 83 & 89.25 & 64 & 65.31 \\
$24-29$ & 10 & 10.75 & 23 & 23.47 \\
$30-35$ & - & & 11 & 11.22 \\
Gender & & & & \\
Male & 25 & 26.88 & 37 & 37.76 \\
Female & 68 & 73.12 & 61 & 62.24 \\
Educational levels & & & & \\
High School & 76 & 81.72 & 67 & 68.37 \\
University & 17 & 18.28 & 31 & 31.63 \\
\hline
\end{tabular}

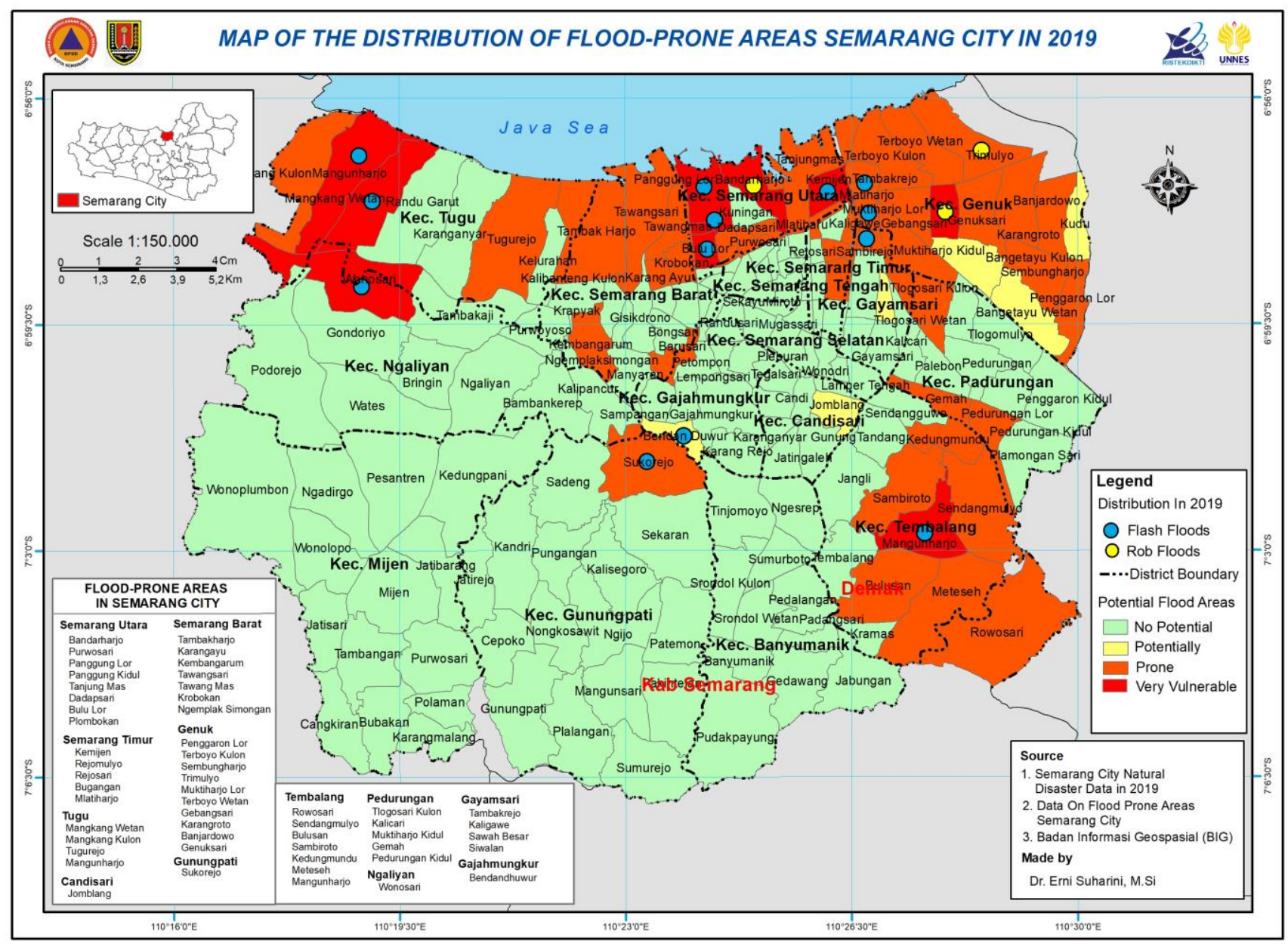

Figure 1. Research location map 
Table 2. The assessment and categorization of youth participation in disaster management activities

\begin{tabular}{cc}
\hline Interval score $(\%)$ & Category \\
\hline$\leqq 20$ & Very Low \\
$21-40$ & Low \\
$41-60$ & Moderate \\
$61-80$ & High \\
$\geqq 81$ & Very High \\
\hline
\end{tabular}

The arranged instrument was tested on 80 people randomly outside the sample group. The test results were then tested by Pearson's correlation with a confidence level of $95 \%$ and declared valid $(r>0.80)$, while the reliability test stated that the instrument is reliable (Cronbach- $\alpha=0.984$ ). Youth participation rates were measured based on the percentage of the number of respondents who carry out disaster preparedness activities. The level of participation was then clustered and assessed according to the level of categories (Table 2).
The data obtained were statistically analyzed using the nonparametric Mann-Whitney test to find out significant differences between respondents' responses from the affected and unaffected areas. Data analysis is based on path analysis where planning is used as a basic variable that influences every disaster response activity. Path analysis is continued by testing the effect of each disaster response activity (variable) on flood disaster management. The impact between variables was measured using the SmartPLS application (v3.2.8) [33] and described descriptively-narratively.

\section{RESULT}

Youth participation in increasing disaster preparedness is an important point in achieving a firm community. The results of the identification of youth participation in affected and unaffected areas by flood in Semarang City show a significant difference in all aspects (Table 3).

Table 3. The levels of respondents' participation in flood disaster management activities in flood-affected and unaffected areas in Semarang City

\begin{tabular}{|c|c|c|c|c|c|c|}
\hline \multirow{2}{*}{ Activity Statements per Step* } & \multicolumn{3}{|c|}{ Unaffected (93 resp) } & \multicolumn{3}{|c|}{ Affected (98 resp) } \\
\hline & f & $\%$ & Category & $\mathbf{f}$ & $\%$ & Category \\
\hline \multicolumn{7}{|l|}{ Planning (PI) } \\
\hline Know the roles and tasks in flood disaster management. & 24 & 25.26 & Low & 81 & 82.65 & Very High \\
\hline $\begin{array}{l}\text { Ensure the conditions of electrical installations, gas, and/or important documents are } \\
\text { safe or secured. }\end{array}$ & 24 & 25.26 & Low & 88 & 89.80 & Very High \\
\hline Ensure that evacuation routes are safe and free of obstacles. & 39 & 41.05 & Medium & 71 & 72.45 & High \\
\hline Know the final evacuation location of flood disaster which is closest to the residence. & 30 & 31.58 & Low & 79 & 80.61 & Very High \\
\hline $\begin{array}{l}\text { Help to prepare an early warning system (making warning signs of rising river water, } \\
\text { marking dangerous places during flooding, and involving village officials). }\end{array}$ & 12 & 12.63 & Very Low & 46 & 46.94 & Medium \\
\hline Perform a flood disaster simulation with all village officials. & 1 & 1.05 & Very Low & 38 & 38.78 & Low \\
\hline \multicolumn{7}{|l|}{$\begin{array}{ll}\text { Mitigation } \\
\end{array}$} \\
\hline Maintain the cleanliness of drains around the house. & 4 & 4.21 & Very Low & 87 & 88.78 & Very High \\
\hline Participate in cooperation activities to clean the environment and waterways. & 77 & 81.05 & Very High & 77 & 78.57 & High \\
\hline Avoid throwing garbage in drains or waterways. & 82 & 86.32 & Very High & 92 & 93.88 & Very High \\
\hline Plant trees in watersheds or mountainous areas. & 34 & 35.79 & Low & 53 & 54.08 & Medium \\
\hline Persuade residents to do community service to clean water sources. & 27 & 28.42 & Low & 68 & 69.39 & High \\
\hline \multicolumn{7}{|l|}{ Emergency Respond } \\
\hline Pay attention to the condition of family members who are sick or have special needs. & 47 & 49.47 & Medium & 90 & 91.84 & Very High \\
\hline $\begin{array}{c}\text { Access announcements and directions from officers to take independent evacuation } \\
\text { measures. }\end{array}$ & 29 & 30.53 & Low & 70 & 71.43 & High \\
\hline Move and turn off electronic stuff when floods come. & 41 & 43.16 & Medium & 89 & 90.82 & Very High \\
\hline Evacuate livestock or pets once flooding occurs. & 16 & 16.84 & Very Low & 56 & 57.14 & Medium \\
\hline Turn off the electricity when floods come. & 47 & 49.47 & Medium & 90 & 91.84 & Very High \\
\hline Responsible for bringing vulnerable/elderly/special needs families to a safe place(s). & 21 & 22.11 & Low & 77 & 78.57 & High \\
\hline \multicolumn{7}{|l|}{ Adaptation } \\
\hline Divide the roles and tasks of each family member in & 3 & 3.16 & Very Low & 74 & 75.51 & High \\
\hline $\begin{array}{l}\begin{array}{l}\text { Use the flood info, weather, and flood warning status application to avoid the effects } \\
\text { of flooding. }\end{array} \\
\end{array}$ & 15 & 15.79 & Very Low & 61 & 62.24 & High \\
\hline $\begin{array}{l}\text { Prepare abilities to deal with flood disasters independently (can swim, prepare buoys, } \\
\text { inflatable boats, and or self-rescue equipment). }\end{array}$ & 22 & 23.16 & Low & 65 & 66.33 & High \\
\hline Join in the disaster preparedness forum both at the neighborhood level and higher. & 2 & 2.11 & Very Low & 38 & 38.78 & Low \\
\hline Prepare medicines and food that are easy to carry and last long. & 28 & 29.47 & Low & 86 & 87.76 & Very High \\
\hline Have a flood disaster standby bag. & 6 & 6.32 & Very Low & 51 & 52.04 & Medium \\
\hline \multicolumn{7}{|l|}{ Rehabilitation } \\
\hline Discard food affected by the flood as an important thing to do. & 70 & 73.68 & High & 87 & 88.78 & Very High \\
\hline $\begin{array}{l}\text { Actively participate in cleaning furniture, clothing, and or houses from the rest of the } \\
\text { flood. }\end{array}$ & 33 & 34.74 & Low & 88 & 89.80 & Very High \\
\hline Help neighbors in cleaning up their houses and surroundings after a flood. & 7 & 7.37 & Very Low & 59 & 60.20 & High \\
\hline \multicolumn{7}{|l|}{ Evaluation } \\
\hline Discuss the implementation of steps to deal with floods with peers. & 23 & 24.21 & Low & 63 & 64.29 & High \\
\hline $\begin{array}{l}\text { Report all actions are taken and damage and losses to the neighborhood }(R T) \text {, hamlet } \\
\qquad(R W) \text {, and related officers. }\end{array}$ & 8 & 8.42 & Very Low & 43 & 43.88 & Medium \\
\hline Evaluate family preparedness plans for dealing with floods. & 29 & 30.53 & Low & 62 & 63.27 & High \\
\hline
\end{tabular}

Note: *) the statements are developed from Law No. 24 of 2007 on Disaster Management 
Table 4. Differences in the average score of respondents' participation based on the variable of disaster management stages

\begin{tabular}{ccccccc}
\hline \multirow{2}{*}{ Aspects } & \multicolumn{3}{c}{ Unaffected (93 resp) } & \multicolumn{3}{c}{ Affected (98 resp) } \\
& $\mathbf{F}$ & $\mathbf{\%}$ & Category & F & \% & Category \\
\hline Planning (Pl) & 21.67 & $22.81^{\mathrm{a}}$ & Low & 67.17 & $68.54^{\mathrm{b}}$ & High \\
Mitigation (Mt) & 44.80 & $47.16^{\mathrm{a}}$ & Medium & 75.40 & $76.94^{\mathrm{b}}$ & High \\
Emergency Respond (ER) & 33.50 & $35.26^{\mathrm{a}}$ & Low & 78.67 & $80.27^{\mathrm{b}}$ & Very High \\
Adaptation (Ad) & 12.67 & $13.33^{\mathrm{a}}$ & Very Low & 62.50 & $63.78^{\mathrm{b}}$ & High \\
Rehabilitation (Rh) & 36.67 & $38.60^{\mathrm{a}}$ & Low & 78.00 & $79.59^{\mathrm{b}}$ & High \\
Evaluation (Ev) & 20.00 & $21.05^{\mathrm{a}}$ & Low & 56.00 & $57.14^{\mathrm{b}}$ & Medium \\
\hline
\end{tabular}

Note: the letters (a-b) show a significant difference between the average percentage of respondents' participation. $\mathrm{F}=$ frequency or number of participant; percent symbol $(\%)=$ participation score

Table 5. The direct effect between the variable of disaster preparedness and flood disaster management

\begin{tabular}{ccccccccc}
\hline \multirow{2}{*}{ Variables } & \multicolumn{4}{c}{ Unaffected } & \multicolumn{4}{c}{ Affected } \\
\cline { 2 - 9 } & OS & SM & SD & p-value & OS & SM & SD & p-value \\
\hline $\mathrm{Pl} \rightarrow \mathrm{DM}$ & -0.043 & -0.046 & 0.610 & 0.483 & 0.371 & 0.364 & 0.037 & $0.000^{* *}$ \\
$\mathrm{Mt} \rightarrow \mathrm{DM}$ & 0.046 & 0.035 & 0.055 & 0.403 & 0.589 & 0.585 & 0.029 & $0.002^{* *}$ \\
$\mathrm{ER} \rightarrow \mathrm{DM}$ & 0.905 & 0.890 & 0.052 & $0.000^{* *}$ & 0.490 & 0.550 & 0.032 & $0.013^{* *}$ \\
$\mathrm{Ad} \rightarrow \mathrm{DM}$ & 0.013 & 0.229 & 0.061 & 0.837 & 0.507 & 0.503 & 0.042 & $0.000^{* *}$ \\
$\mathrm{Rh} \rightarrow \mathrm{DM}$ & 0.002 & 0.006 & 0.071 & 0.980 & -0.014 & -0.013 & 0.016 & 0.387 \\
$\mathrm{Ev} \rightarrow \mathrm{DM}$ & -0.060 & -0.029 & 0.062 & 0.334 & 0.200 & 0.198 & 0.032 & $0.000^{* *}$ \\
\hline
\end{tabular}

Note: Asterisk $(* *)$ indicates the relation of a significant impact. Variables explanation, $\mathrm{Pl}=$ planning step; $\mathrm{Mt}=\mathrm{mitigation}$ step; ER $=$ emergency respond; Ad $=$ adaptation; $\mathrm{Rh}=$ rehabilitation; $\mathrm{Ev}=$ evaluation; and $\mathrm{DM}=$ disaster management. SmartPLS statically explanation, OS $=$ original sample of correlation direction $(+/-) ; \mathrm{SM}=$ sample mean; $\mathrm{SD}=$ standard deviation; and $p$-value $=$ significance level $\leq 0.05$.

Table 6. The indirect effect of planning on flood disaster management through disaster preparedness variable

\begin{tabular}{lcccccccc}
\hline \multirow{2}{*}{ Variables } & \multicolumn{4}{c}{ Unaffected } & \multicolumn{4}{c}{ Affected } \\
\cline { 2 - 9 } & OS & SM & SD & p-value & OS & SM & SD & p-value \\
\hline $\mathrm{Pl} \rightarrow \mathrm{Mt} \rightarrow \mathrm{DM}$ & 0.011 & 0.013 & 0.014 & $0.000^{* *}$ & 0.026 & 0.028 & 0.014 & $0.025^{* *}$ \\
$\mathrm{Pl} \rightarrow \mathrm{ER} \rightarrow \mathrm{DM}$ & 0.436 & 0.433 & 0.076 & 0.435 & 0.250 & 0.029 & 0.017 & $0.006^{* *}$ \\
$\mathrm{Pl} \rightarrow \mathrm{Ad} \rightarrow \mathrm{DM}$ & 0.000 & 0.013 & 0.031 & 0.435 & 0.362 & 0.364 & 0.037 & $0.000^{* *}$ \\
$\mathrm{Pl} \rightarrow \mathrm{Rh} \rightarrow \mathrm{DM}$ & 0.006 & 0.003 & 0.020 & 0.847 & -0.004 & -0.004 & 0.006 & 0.432 \\
$\mathrm{Pl} \rightarrow \mathrm{Ev} \rightarrow \mathrm{DM}$ & 0.005 & 0.004 & 0.014 & 0.745 & 0.094 & 0.097 & 0.022 & $0.000^{* *}$ \\
\hline
\end{tabular}

Note: Asterisks (**) point out the relation of a significant impact. Variables explanation, $\mathrm{Pl}=$ planning step; Mt $=$ mitigation step; ER $=$ emergency response; Ad $=$ adaptation; $\mathrm{Rh}=$ rehabilitation; $\mathrm{Ev}=$ evaluation; and $\mathrm{DM}=$ disaster management. SmartPLS statistical explanation, OS $=$ original sample of correlation direction (+/-); $\mathrm{SM}=$ sample mean; $\mathrm{SD}=$ standard deviation; and $p$-value $=$ significance level $\leq 0.05$.

Respondents in unaffected areas by floods in Semarang City have a lower level of participation except at community service and properly disposing of waste activities. This is likely due to the cooperation culture and high waste disposal as a result of the anti-plastic campaign that the city government has been promoting. However, overall, the level of participation in flood disaster management takes place in the low category. This finding is in sharp contrast to the level of respondent participation in affected areas by floods which is categorized as high. Low participation was only found in simulation activities and participation as members of flood disaster preparedness groups. Nonetheless, the level of youth participation in these two activities is far higher than the participation of youth from the affected areas (Table 3).

Young people in unaffected areas have a level of participation in disaster management at each stage, which on average, shows lower $(p=0.00)$ than youth in areas affected by floods (Table 4). This indicates that knowledge related to disaster management is still limited to areas affected by disasters and has not been well distributed to all groups in Semarang City.

The planning aspects predominantly influence emergency response and adaptation activities, both in the attitudes of youth in affected and unaffected areas (Figure 2). This exemplifies that youth are more proactive or more responsive when disasters occur. Besides, in unaffected areas, planning has a low influence on rehabilitation activities and does not affect mitigation and evaluation activities.

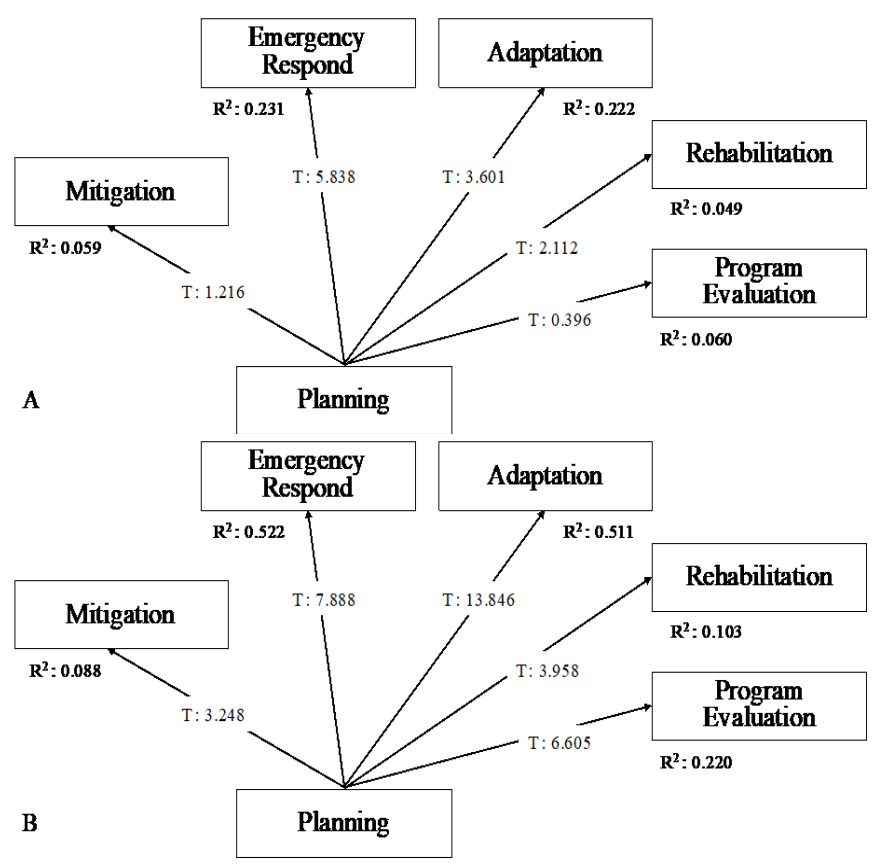

Figure 2. The impact score of planning on other variables of disaster management in unaffected areas (A) and affected areas (B)

$\mathrm{T}=$ score of $T_{\text {count }}$, the impact of planning on other aspects is indicated by the score of $\mathrm{T}_{\text {count }}>\mathrm{T}_{\text {table }} 1.985 . \mathrm{R}^{2}=$ linear regression score with $\alpha=0.05$, pointing out the effect of variables by being converted into percentages. 
In flood-affected areas, planning activities show a significant effect on other aspects even though it is below $23 \%$ (Figure 2). The impact of planning on mitigation activities denotes that youth in flood-affected areas may begin to realize the role of prevention in the severity of flood impacts. The facts found in the field also point that young people affected by floods have sensitivity in environmental rehabilitation activities, and make improvements to disaster management that has been done. Overall, once they face a disaster situation, it is likely that youth in both regions will have high disaster management actions $(>80 \%)$. This is indicated by the magnitude of the effect of disaster response activities in flood management (Figure 3).

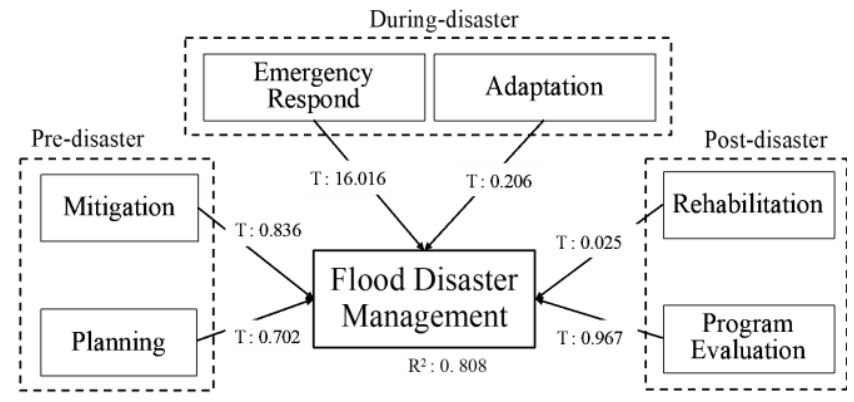

A

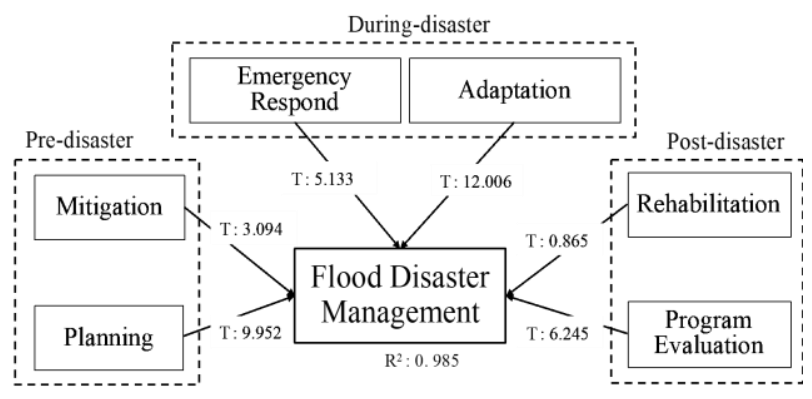

B

Figure 3. The participatory variable score for flood disaster management in unaffected areas (A), and areas affected by flood disaster (B)

Based on path analysis, the hypothesis test of preparedness activities in developing disaster management shows the effect of correlation following the participatory score. All preparedness activities in unaffected areas do not have a direct effect on flood disaster management as indicated by a $p$ score of more than 0.05 , except for emergency response activities (Table 5). In flood-affected areas, all activities/stages carried out have a significant impact on disaster management ( $p$-value $<0.05$ ) except for rehabilitation activities. This exemplifies that there is an impact given by disaster preparedness activities to the flood disaster management undertaken.

Besides the direct effect, the hypothesis test for the indirect effect also shows that it points out differences in both areas. In unaffected areas, there is an indirect indication that the combination of planning and activities significantly influences flood disaster management except in mitigation activities and except for rehabilitation activities in affected areas (Table 6). However, planning directly gives impact to rehabilitation activities by $10.4 \%$ (Figure 2 ), while rehabilitation activities do not affect disaster management (Table 5). This is likely because rehabilitation activities are currently more focused on physical activities, and have not been comprehensive enough to improve the quality of life of flood victims.

\section{DISCUSSION}

Planning activities are part of the pre-disaster stages which aim to formulate all stages or areas of disaster by identifying disasters' potentials. In the pre-disaster phase, planning activities include the alertness of preparation plans (Figure 4) to deal with potential disasters or emergencies [34]. It is the main foundation of disaster management fruitfulness, and is proved to play important role in reducing economic and social losses [35]. The planning is based on a specific disaster scenario or single hazard, called the Contingency Plan [36-38], in this case, the flood disaster. Contingency Plans involve various groups and agencies including youth, where youth are required to play an active role in disaster management planning [27, 38]. But in fact, the role of youth in disaster management has not received a large portion at the time being. This is because the movement is still dominated by the old ones. This is ironic, as youth have a vital role and cannot be ignored in the implementation of disaster management, especially in mitigation and emergency response [30].

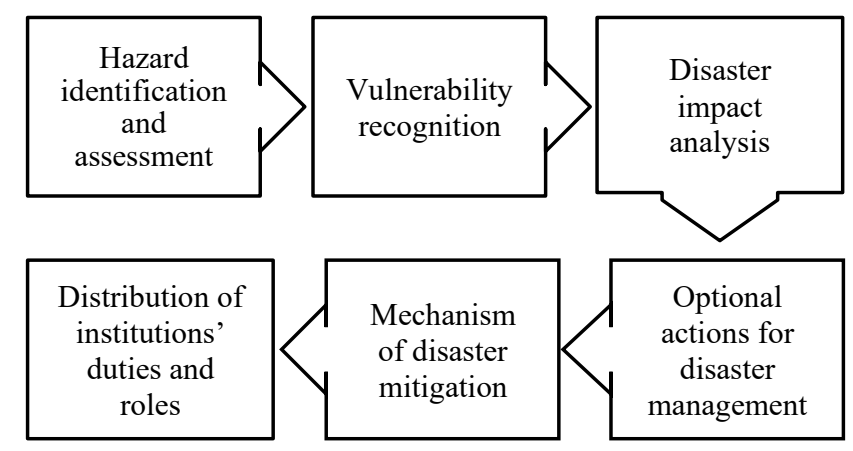

Figure 4. Preparation/arrangement of disaster management plans (source: developed from Indonesian National Board for Disaster Management)

Planning activities include the formulation of plans to carry out the management of the damage that might occur. Disaster management planning has a significant effect on disaster preparedness activities but possesses a weak influence on mitigation, rehabilitation, and evaluation activities. We assume the weak correlation may be caused by low involvement among community members and other parties in contingency plan arrangement-the fixed contingency plan is just developed by the government and directly delivered to the community (top to down).

Mitigation is an activity that is included in the pre-disaster phase by increasing ecological services and improving the ability of the environment to deal with disasters [39]. In this case, flood mitigation can be conducted either through improvement/ physical development [40-42], as well as awareness, behaviors, and escalation of the ability to face the threat of disaster [43, 44]. However, based on observations, mitigation activities undertaken by respondents are temporary and ceremonial. For example, mangrove planting activities in coastal areas and trees in water catchment areas are ceremonial events without any follow-up or monitoring and evaluation of seedling growth. The majority of participants in planting activities are also from elementary and junior high school children whose emotional maturity has not yet developed in understanding the basic objectives of planting. Lack of postplanting supervision has resulted in dead seedlings and ineffective planting programs. This shows that the mitigation activities are not performed comprehensively and seemed to 
be original. The impact of these problems is the low participation of respondents in mitigation activities and the absence of awareness of protecting the environment to prevent disasters.

Based on disaster management rules, the planning process shifts from contingency plans to operational plans when disasters occur directly to victims [45]. After that, they turn into recovery plans including post-disaster rehabilitation and reconstruction plans [41]. Planning of both flood-affected and unaffected youth shows similarities; there is a very low effect on rehabilitation and evaluation activities. This might be caused by rehabilitation models that are not well planned, the process of post-disaster rehabilitation activities, more emphasis on building repairs and physical facilities, and rarely on improving handling post-disaster trauma activities. Rehabilitation activities are still incidental adjusting the damage that has occurred and has not yet thoroughly formulated post-disaster trauma management. This is likely due to the community that has not yet been aware of the problem of psychological conditions and assumes that flood is a common natural disaster. It becomes a sort of unfortunate because, through rehabilitation activities, awareness of the conditions of the flood disaster can be conveyed more meaningfully [46].

Overall, the level of youth participation exhibits that the impacts of the flood disaster directly affect the role of youth in the planning aspect. Active youth involvement, especially in areas affected by flooding, is mainly influenced by community awareness-raising programs and early flood warning systems. In fact, in areas directly affected by floods, some people have formed the Disaster Preparedness Group (Kelompok Siaga Bencana or KSB), which aims to increase community preparedness in dealing with floods. The formation of KSB is carried out in a focused manner in 3 districts and 8 sub-district by involving non-government organizations (NGOs), academics, and local governments. The areas are chosen based on flood-affected areas, especially of the Kaligarang River (the main river in Semarang City) or tidal floods from the North Java Sea. The establishment of the KSB indicates the awareness and willingness of the community are more resilient and firmer in dealing with disasters. But, even so, the program should be improved to improve flood disaster preparedness, especially in multi-stakeholder partnership around watershed areas [47].

Also, the formation of the KSB begins with disaster education activities, which include socialization, training, and simulations. Education has an impact on the knowledge of youth about what should and should not be done in disaster management [8, 48, 49]. Therefore, youth in flood-affected areas have a higher level of participation in almost all flood disaster management activities. Furthermore, almost $50 \%$ of respondents in that area are also involved in preparing a community-based early warning system. The early flood warning system is an activity to predict (estimate) in advance related to the magnitude and when the flood will occur so that related information can be distributed to affected communities [15]. The early warning system incorporates communication technology and social cooperation so that flooding can be anticipated to avoid further damage and losses [50].

Flood disaster management in Semarang City is arranged based on the results of flood disaster risk analysis and mitigation efforts. Mitigation efforts consist of prevention, mitigation, and preparedness included in the Long-Term Development Plan, Medium-Term Development Plan, and the annual Government Work Plan of Semarang City. Based on these regulations, flood management activities and disaster education are only focused on areas directly affected by floods, which then result in low youth participation in flood disaster management outside the area.

It is necessary to expand the education and management of flood disasters beyond the flood-affected areas. Low levels of participation in disaster preparedness can be overcome through education [47], simultaneous disaster simulations, and installing safety instructions and early warning system [51], providing emergency response equipment, making evacuation plans, and continuing to discuss with people what to do during and after a disaster [52-54]. That is because as a whole, the people of Semarang City outside the affected areas also have a stake in preventing floods. Expanding education and flood disaster management can be done by adjusting the portion of material according to the needs of the community in each region $[9,55]$. Communities in upstream or urban areas that are relatively safe from disaster can carry out mitigation activities by performing periodical tree planting and monitoring, making infiltration wells, and managing waste properly to reduce the risk of flooding. A high level of participation will increase awareness of disasters to reduce the occurrence of greater losses due to floods [56, 57]. Youth participation and components of society as a whole are expected to improve self-preparedness for disaster anticipation early on. We also realize it needs more understandings, especially different perspectives on the physical condition such as drainage condition in the unaffected and affected areas, that may affect the youth perspective, encourage the government and researcher to conduct other studies.

\section{CONCLUSION}

The level of youth participation in the implementation of flood disaster management is strongly influenced by the experience of flood exposure both due to overflowing river water and rob. Youth participation in areas affected by floods proved to be higher and significantly different from youth participation in unaffected areas. Flood disaster management actions including planning, mitigation, emergency response, adaptation, rehabilitation, and evaluation have a great impact on flood disaster management activities in Semarang City. Flood disaster planning is proven to affect activities in the stages of disaster management, and weak planning is correlated with the low contribution of mitigation, rehabilitation, and evaluation to disaster management. Weak phases of disaster management planning among youth are possibly caused by the fact that youth have not been involved in the preparation of a flood disaster contingency plan ideally.

The level of youth participation is deemed necessary to be increased to develop a more comprehensive disaster management program according to regional needs. Youth, both in affected or unaffected areas, need to get an education, outreach, training, and/or flood disaster response simulations. This has to be conducted to improve youth awareness of the importance of disaster management.

\section{ACKNOWLEDGMENT}

We greatly thank Universitas Negeri Semarang for funding this research through an applied research scheme in 2019. 


\section{REFERENCES}

[1] Ali, R.A., Mannakkara, S., Wilkinson, S. (2020). Factors affecting successful transition between post-disaster recovery phases: A case study of 2010 floods in Sindh, Pakistan. International Journal of Disaster Resilience Built Environment, 11(5): 597-614. https://doi.org/10.1108/IJDRBE-03-2020-0016

[2] Seddon, N., Chausson, A., Berry, P., Girardin, C.A.J., Smith, A., Turner, B. (2020). Understanding the value and limits of nature-based solutions to climate change and other global challenges. Philosophical Transactions of the Royal Society B Biological Sciences, 375(1794): 20190120. https://doi.org/10.1098/rstb.2019.0120

[3] Yang, C., Su, G., Chen, J. (2017). Using big data to enhance crisis response and disaster resilience for a smart city. 2017 IEEE 2nd International Conference on Big Data Analysis (ICBDA). Beijing, pp. 504-507. https://doi.org/10.1109/ICBDA.2017.8078684

[4] Ashraf, S., Luqman, M., Iftikhar, M., Ashraf, I. (2017). Understanding flood risk management in Asia: Concepts and challenges. In: Hromadka, T.V., Rao, P. (eds) Flood Risk Management. IntechOpen, London. https://doi.org/10.5772/intechopen.69139

[5] Hapsari, R.I., Zenurianto, M. (2016). View of flood disaster management in Indonesia and the key solutions. American Journal of Engineering and Research, 5(3): 140-151.

http://www.ajer.org/papers/v5(03)/T050301400151.pdf.

[6] Ogie, R.I., Holderness, T., Dunn, S., Turpin, E. (2018). Assessing the vulnerability of hydrological infrastructure to flood damage in coastal cities of developing nations. Computers, Environment and Urban Systems, 68: 97-109. https://doi.org/10.1016/j.compenvurbsys.2017.11.004

[7] Sari, A.D., Prayoga, N. (2018). Enhancing citizen engagement in the face of climate change risks: A case study of the flood early warning system and health information system in Semarang City, Indonesia. In: Hughes, S., Chu, E., Mason, S. (eds) Climate Change in Cities. The Urban Book Series. Springer, Cham. https://doi.org/10.1007/978-3-319-65003-6_7

[8] Amin, C., Sukamdi, S., Rijanta, R. (2018). Exploring typology of residents staying in disaster-prone areas: A case study in Tambak Lorok, Semarang City, Indonesia. $\begin{array}{lll}\text { Forum } & \text { Geografi, } & \text { 24-37. }\end{array}$ https://doi.org/10.23917/forgeo.v32i1.5817

[9] Buchori, I., Pramitasari, A., Sugiri, A., Maryono, M., Basuki, Y., Sejati, A.W. (2018). Adaptation to coastal flooding and inundation: Mitigations and migration pattern in Semarang City, Indonesia. Ocean \& Coastal Management, 163: 445-455. https://doi.org/10.1016/j.ocecoaman.2018.07.017

[10] Suhelmi, I.R., Triwibowo, H. (2018). Coastal inundation adaptive strategy in Semarang coastal area. Forum Geografi., 32(2): 195-203. https://doi.org/10.23917/forgeo.v32i2.5672

[11] Nugraha, A.L., Hani'ah, H., Pratiwi, R.D. (2017). Assessment of multi hazards in Semarang City. 2nd Geoplanning - International Conference on Geomatics and Planning, Surakarta, pp. 1-9. https://doi.org/10.1063/1.4987112

[12] Vicerra, M.P., Salvador, J.M.G., Capili, Y.M.V. (2018). Disaster preparedness knowledge and action: Population development perspective. Asia Pacific Journal of
Multidiscipline. Research, 6(61): 103-109. http://www.apjmr.com/wpcontent/uploads/2018/01/APJMR-2017.6.1.13.pdf.

[13] Fothergill, A. (2017). Children, Youth, and Disaster. Oxford Research Encyclopedia of Natural Hazard Science. Oxford https://doi.org/10.1093/acrefore/9780199389407.013.23

[14] Miladan, N. (2016). Communities' contributions to urban resilience process: A case study of Semarang City (Indonesia) toward coastal hydrological risk. (Thesis). Architecture, Space Management. Université Paris-Est. Paris.

[15] Yuniartanti, R.K., Handayani, W., Waskitaningsih, N. (2016). Monitoring and evaluation effectiveness in flood early warning system project in Semarang City. International Journal of Social System and Science, 8(1): 49-77. https://doi.org/10.1504/IJSSS.2016.076004

[16] Maimunah, S., Rosli, N., Rafanoharana, S., Sari, K., Higashi, O. (2011). Strengthening community to prevent flood using participatory approach (a case of the Semarang City). Journal of International Development and Cooperation, 18(2): 19-28. https://doi.org/10.15027/32463

[17] Kurniawati, W., Mussadun, M., Nugraha, M.F. (2020). Spatial expression of Malay Kampung Semarang in facing flood disaster. In: the 1st International Conference on Urban Design and Planning, Semarang, p. 012049. https://doi.org/10.1088/1755-1315/409/1/012049/meta

[18] Indrayati, A., Aji, A., Hikmah, N. (2018). 3D model and morphometry of the Beringin watershed as an effort for flash flood disaster risk reduction in Semarang. In: MATEC Web Conf. International Conference on Disaster Management (ICDM 2018), Padang, p. 04010. https://doi.org/10.1051/matecconf/201822904010

[19] Widyasamratri, H., Aswad, A. (2017). A preliminary study: An agent-based spatial simulation of humancoastal environment interaction. In Proceedings of International Conference: Problem, Solution and Development of Coastal and Delta Areas C, Semarang, pp. 593-601. http://jurnal.unissula.ac.id/index.php/ICCDA/article/vie w/2044/1567.

[20] van de Haterd, J., Budiyono, B., Darundiati, Y.H., Spaan, E. (2020). Environmental change and health risks in coastal Semarang, Indonesia: Importance of local indigenous knowledge for strengthening adaptation policies. Cities \& Health, 4: 1-13. https://doi.org/10.1080/23748834.2020.1729451

[21] Suharini, E., Kurniawan, E., Ichsan, I.Z. (2020). Disaster mitigation education in the COVID-19 pandemic: A case study in Indonesia. Sustainability: The Journal of Record, 13(6): 292-298. https://doi.org/10.1089/sus.2020.0053

[22] Octastefani, T., Rum, M. (2019). Millennials' contribution in disaster risk reduction: Case study of tidal flooding in Semarang. Jurnal Ilmu Sosial dan Ilmu Politik, 23(1): 14-29. https://doi.org/10.22146/jsp.43727

[23] Janicke-Bowles, S., Nayaran, A., Seng, A. (2018). Social media for good? A survey on millennials' inspirational social media use. Journal of Social Media in Society, 7(2): 120-140. https://thejsms.org/index.php/TSMRI/article/view/381/1 94.

[24] Cox, R.S., Scannell, L., Heykoop, C., Tobin-Gurley, J., Peek, L. (2017). Understanding youth disaster recovery: 
The vital role of people, places, and activities. International Journal of Disaster Risk Reduction, 22: 249-256. https://doi.org/10.1016/j.ijdrr.2017.03.011

[25] Garg, C.V., Sam, A. (2020). Engagement of national cadet corps (NCC) cadets in disaster risk mitigation under pandemic COVID-19: A case study of Tamilnadu, Puducherry and Andaman \& Nicobar Islands. Impact: International Journal of Research in Applied, Natural and Social Sciences (IMPACT: IJRANSS), 8: 15-24.

[26] Cox, J., Finau, G., Kant, R., Tarai, J., Titifanue, J. (2018). Disaster, divine judgment, and original sin: Christian interpretations of tropical cyclone winston and climate change in Fiji. The Contemporary Pacific, 30(2): 380410. https://doi.org/10.1353/cp.2018.0032

[27] Cox, R.S., Hill, T.T., Plush, T., Heykoop, C., Tremblay, C. (2019). More than a checkbox: Engaging youth in disaster risk reduction and resilience in Canada. Natural Hazards, 98(1): 213-227. https://doi.org/10.1007/s11069-018-3509-3

[28] Fletcher, S., Cox, R.S., Scannell, L., Heykoop, C., TobinGurley, J., Peek, L. (2016). Youth creating disaster recovery and resilience: A multi-site arts-based youth engagement research project. Children, Youth and Environment, 26(1): 148-163. https://doi.org/10.7721/chilyoutenvi.26.1.0148

[29] Fernandez, G., Shaw, R. (2015). Youth participation in disaster risk reduction through science clubs in the Philippines. $\quad$ Disasters, 39(2): 279-294. https://doi.org/10.1111/disa.12100

[30] Eker, Y., Yilmabaşar, M. (2018). "Disaster resilient society with youth" project of the civil defence organization aiming disaster risks reduction. The International Archives of the Photogrammetry, Remote Sensing and Spatial Information Sciences - ISPRS, 42(3W4): 205-209. https://doi.org/10.5194/isprsarchives-XLII-3-W4-205-2018

[31] Koumachi, B. (2019). The digital turn in higher education: A "digital natives" mythbusting. International Journal of Technology in Education and Science, 3(1): 69-79. https://files.eric.ed.gov/fulltext/EJ1227047.pdf

[32] Cox, R.S., Hamlen, M. (2015). Community disaster resilience and the rural resilience index. American Behavioral Scientist, 59(2): 220-237. https://doi.org/10.1177/0002764214550297

[33] Ringle, C.M., Wende, S., Becker, J.M. (2015). SmartPLS 3. Boenningstedt SmartPLS GmbH. Germany. http://www.smartpls.com.

[34] Raikes, J., Smith, T.F., Jacobson, C., Baldwin, C. (2019). Pre-disaster planning and preparedness for floods and droughts: A systematic review. International Journal of Disaster Risk Reduction, 38: 101207. https://doi.org/10.1016/j.ijdrr.2019.101207

[35] Samu, R., Akintug, B. (2020). Pre-disaster planning and preparedness: Drought and flood forecasting and analysis in Zimbabwe. Water SA, 46(3): 448-457. https://doi.org/10.17159/wsa/2020.v46.i3.8655

[36] Ohara, M., Nagumo, N., Shrestha, B.B., Sawano. H. (2016). Evidence-based contingency planning to enhance local resilience to flood disasters. In: J. Abbot and A. Hammond, (eds) Recent Advances in Flood Risk Management. IntechOpen. London. https://doi.org/10.5772/intechopen.82312

[37] Boles, W.C. (2019). The science and politics of climate change in steve waters' the contingency plan. Journal of
Contemporary Drama in English, 7(1): 107-122. https://doi.org/10.1515/jcde-2019-0008

[38] Newport, J.K., Moller, J.J., Newport, K.J., Jawahar, G.G. (2017). Community participation in contingency plan preparation towards disaster mitigation. Journal of Earth and Environmental Sciences, 2017(5): 122. https://www.gavinpublishers.com/articles/casestudy/Emergency-Medicine-Investigations/communityparticipation-in-contingency-plan-preparation-towardsdisaster-mitigation.

[39] Cigler, B.A. (2017). U.S. floods: The necessity of mitigation. State and Local Government Review, 49(2): 127-139. https://doi.org/10.1177\%2F0160323X17731890

[40] Mei, C., Liu, J., Wang, H., Yang, Z., Ding, X., Shao, W. (2018). Integrated assessments of green infrastructure for flood mitigation to support robust decision-making for sponge city construction in an urbanized watershed. Science of the Total Environment, 639: 1394-1407. https://doi.org/10.1016/j.scitotenv.2018.05.199

[41] Rehman, J., Sohaib, O., Asif, M., Pradhan, B. (2019). Applying systems thinking to flood disaster management for a sustainable development. International Journal of Disaster Risk Reduction, 36: 101101. https://doi.org/10.1016/j.ijdrr.2019.101101

[42] Lopez, M.G., Di Baldassarre, G., Seibert, J. (2017) Impact of social preparedness on flood early warning systems. Water Resource Research, 53: 522-534. https://doi.org/10.1002/2016WR019387

[43] Babcicky, P., Seebauer, S. (2017). The two faces of social capital in private flood mitigation: Opposing effects on risk perception, self-efficacy and coping capacity. Journal of Risk Research, 20(8): 1017-1037. https://doi.org/10.1080/13669877.2016.1147489

[44] Binh, P.T., Zhu, X., Groeneveld, R.A., van Ierland, E.C. (2020). Risk communication, women's participation and flood mitigation in Vietnam: An experimental study. Land Use Policy, 95: 104436. https://doi.org/10.1016/j.landusepol.2019.104436

[45] Dwirahmadi, F., Rutherford, S., Phung, D., Chu, C. (2019). Understanding the operational concept of a flood-resilient urban community in Jakarta, Indonesia, from the perspectives of disaster risk reduction, climate change adaptation and development agencies. International Journal of Environmental Research and Public Health, 16(20): 3993-4016. https://doi.org//10.3390/ijerph16203993

[46] Hidayati, D. (2018). The role of social capital in enhancing community disaster preparedness and building back better in recovery MATEC Web Conf. 229. International Conference on Disaster Management (ICDM 2018). Padang. https://doi.org/10.1051/matecconf/201822901001

[47] Lamina, O.G. (2017). School-community cooperation in natural disaster education and preparedness in Barangay Dolores, Taytay, Rizal, Philippines. Higher Education Forum: Hong Kong International Conference on the Social Sciences, Hong Kong, pp. 129-144. https://www.academia.edu/38998139/School_Communi ty_Cooperation_in_Natural_Disaster_Education_and_P reparedness_in_Barangay_Dolores_Taytay_Rizal_Phili ppines.

[48] Bosschaart, A., van der Schee, J., Kuiper, W., Schoonenboom, J. (2016). Evaluating a flood-risk 
education program in the Netherlands. Studies in Educational Evaluation, 50: 53-61. https://doi.org/10.1016/j.stueduc.2016.07.002

[49] Suharini, E., Meliana, D., Sanjoto, T., Kurniawan, E. (2020). The strategy of disaster mitigation literacy through problem-based learning (PBL) in the school prone to tidal floods. 1st International Conference on Environment and Sustainability Issues, Semarang. http://dx.doi.org/10.4108/eai.18-7-2019.2290156

[50] Bodoque, J.M., Díez-Herrero, A., Amerigo, M., García, J.A., Olcina, J. (2019). Enhancing flash flood risk perception and awareness of mitigation actions through risk communication: A pre-post survey design. Journal of Hydrology, 568: 769-779. https://doi.org/10.1016/j.jhydrol.2018.11.007

[51] Worowirasmi, T.S., Waluyo, M.E., Rachmawati, Y., Hidayati, I.Y. (2015). The Community-Based Flood Disaster Risk Reduction (CBDRR) in Beringin Watershed in Semarang City. Journal Wilayah dan Lingkung, 3(2):

131. https://doi.org/10.14710/jwl.3.2.131-150

[52] Shariff, N.N.M., Hamidi, Z.S. (2019). Community-based approach for a flood preparedness plan in Malaysia. Jàmbá Journal of Disaster Risk Studies, 11(1): 1-6. https://doi.org/10.4102/jamba.v11i1.598

[53] Rogayan, D.V., Dollete L.F. (2020). Disaster awareness and preparedness of barrio community in Zambales,
Philippines: Creating a baseline for curricular integration and extension program. Review of International Geography Education, 10(2): 92-114. https://doi.org/10.33403/rigeo.634564

[54] Nifa, F.A.A., Abbas, S.R., Lin, C.K., Othman, S.N. (2017). Developing a disaster education program for community safety and resilience: The preliminary phase. In the $2^{\text {nd }}$ International Conference on Applied Science and Technology 2017 (ICAST'17), Kedah. https://doi.org/10.1063/1.5005338

[55] Martuti, N.K.T., Pribadi, R., Sidiq, W.A.B.N., Mutiatari, D.P. (2020). Community-Based integrated coastal management strategy in Tugurejo Subdistrict, Semarang. Advances in Social Science, Education and Humanities Research, 390(ICRACOS 2019): 73-80. https://doi.org/10.2991/icracos-19.2020.15

[56] Inayati, D., Suharini, E., Sriyono, S. (2017). Level of population participation in the preservation of mangrove plants in Pecakaran Village, Pekalongan Regency. Edu Geography, $\quad 5(1)$ : $52-59$. https://journal.unnes.ac.id/sju/index.php/edugeo/article/ view/13743.

[57] Suharini, E., Asiah, S., Kurniawan, E. (2020). The role of community-based disaster preparedness and response team in building community resilience. Malaysian Journal of Society and Space, 16(4): 30-44. https://doi.org/10.17576/geo-2020-1604-03 